\title{
Exploring the real costs of healthcare-associated infections: an international review
}

\author{
João Moura ${ }^{a}$, Pilar Baylina ${ }^{\mathrm{b}}$ and Paulo Moreira ${ }^{\mathrm{c}, \mathrm{d}}$
}

\begin{abstract}
${ }^{a}$ Associação de Politécnicos do Norte, Instituto Politécnico do Porto, Portugal; ${ }^{b}$ Escola Superior de Saúde do Porto, Instituto Politécnico do Porto, Portugal; ' Instituto para as Políticas Públicas e Sociais, ISCTE - Instituto Universitário de Lisboa, Lisboa, Portugal; ${ }^{d}$ Universidade Atlântica, Lisboa, Portugal
\end{abstract}

\begin{abstract}
Purpose: Healthcare-associated infections acquired a high degree of dissemination, being considered a serious public health problem and assumed as one of the most common adverse events associated with healthcare. They have a significant impact on health systems by increasing hospital expenses, and compromising the healthcare quality and effectiveness. Surgical site infections (SSI) are considered one of the most serious complications that can occur after an orthopaedic surgery. The aim of this study is to contribute to the development of a framework to analyse the costs of infections related to hip and knee arthroplasties.

Methods: A literature review was conducted on databases, and articles published between January 2005 and April 2016 were searched.

Findings: A total of 14 articles met the inclusion criteria. Costs were grouped in hospitalization and treatment dimensions. For hospitalization, the indicators were the length of stay (LOS) and/ or monetary costs; For treatment, the indicators were number of surgeries and LOS, or monetary costs. We observed that LOS is the most commonly used to estimate SSI direct costs. Patients who developed hip or knee arthroplasty infections remained in hospital 2.5-3 times longer and incurred hospital costs almost three times higher, when compared with an uninfected patient.
\end{abstract}

\author{
KEYWORDS \\ Hip and knee arthroplasties; \\ healthcare-associated \\ infections (HAl); surgical site \\ infections (SSI); length of \\ stay; costs
}

\section{Introduction}

Nosocomial infections, currently named by healthcareassociated infections (HAI), are according to the European Centre of Disease Prevention and Control (ECDC) and the National Nosocomial Infection Surveillance (NNIS), those arising from adverse reactions to the presence of an infectious agent or its toxins, but they were not expressed neither undergoing an incubation period, at the time of patient's admission to the hospital $[1,2]$.

Currently, these have acquired a high degree of dissemination, being considered a serious public health problem. HAIs are assumed as one of the most common adverse events associated with healthcare and is estimated that about one in ten hospitalized patients will acquire an infection after admission. Its high transcendence is due to its high morbidity and mortality, having become one of the major causes of death in hospitalized patients [3-5]. Also, these have a very significant impact on health systems by increasing hospital expenses and may compromise the healthcare quality and effectiveness. These extra costs are justified by the increase of the length of stay (LOS) in about 4-8 days for each infected patient, and the additional diagnostics and therapeutic interventions. As a result, patients who developed HAI remained in hospital 2.5 times longer than uninfected patients and incurred hospital costs almost three times higher [3,6,7].

Although it is a very current topic, since the beginning of the 1990s several international projects have been developed in order to improve knowledge about $\mathrm{HAI}$ and at the same time, developed surveillance strategies to promote and guide efforts towards the prevention and control of this kind of infection [8,9]. In this matter is noteworthy the work done by WHO, CDC, OECD, and the Council of Europe in the development of these projects [9], emerged in 1994 in Europe the first international programme of HAI active surveillance, the Hospitals in Europe Link for Infection Control through Surveillance (HELICS), that has been expanding and suffering continuous improvement since then [10]. Since the creation of HELICS, other programmes have been developed, such as 'First Patient Safety Challenge: Clean Care is Safer Care' [11] and 'Second Patient Safety Challenge: Safe Surgery saves lives' [12] by the WHO, 'Prohibit' [13], and 'BURDEN' [14] by the European Union and the HAI-net [15] by ECDC.

However, the impact of these programmes has not been as expected. A group of researchers, through a review article, identified a number of barriers to the success of these programmes, clustered in three 
dimensions: structure, processes, and results [16]. With regard to structures, they referred to the lack of quality of hospital infrastructure; lack of human resources, especially nurses dedicated full-time to HAI prevention and control programmes; hospital environmental contamination and the organization's own culture. With regard to processes, they indicated failures in clinical processes and management processes, such as poor infection control practices, wards management, healthcare teams' management, hospital and cleaning services management and the inappropriate use of resources. With regard to results, all identified barriers are related with the lack of effective surveillance systems and the unreliability of epidemiological data [16].

There are four major groups of HAI: ventilatorassociated pneumonia (VAP), catheter-associated urinary tract infections, surgical site infections (SSI), and bloodstream infections (CLABSI). In this systematic literature review, our attention turned to the SSI, focusing on the orthopaedics area, selecting only those associated with hip or knee arthroplasties.

This work is organized in four major chapters: the first is a brief introduction to hip and knee arthroplasty infections; in the second is presented the methodology used, including database search, data collection, and analysis; the third chapter is dedicated to results presentation; and in the final chapter are presented the study's conclusions.

\section{Hip and knee arthroplasty infections}

As the average life expectancy is increasing in industrialized countries, the number of patients who need orthopaedic implant surgery also increases, accentuating the risk of developing a greater number of infections [17].

SSI are considered one of the most serious complications that can occur after arthroplasty [18] and between 1.5 and $2.5 \%$ of all knee and hip arthroplasties tend to become infected [19]. In agreement with previous reports, these values can range between 2 and $6 \%[20]$.

The LOS is one of the factors that suffers the biggest changes when the patient gets an infection, and it is the indicator most commonly used to estimate the direct costs of SSI [21].

Despite the increase of the hospitalization costs, SSI also represent a major clinical problem leading to painful and persistent symptoms in infected patients, need for new surgical interventions, extra antibiotic treatments, and casual removal or replacement of the prosthesis and, in more severe cases to save the patient, a local amputation is performed [22-24].

The presence of microorganisms on the prosthesis surface is one of the preconditions for the infection occurrence. The most often bacteria related with orthopaedic implant infections are Staphylococcus aureus and
Staphylococcus epidermidis, particularly the first agent that is responsible for most of these infections, which are especially difficult to treat when caused by Methicillin-resistant Staphylococcus aureus (MRSA) [20,25].

There is evidence that, for example, if the screening and the decolonization of Staphylococcus aureus in hip or knee replacement surgeries was carried out, about seven times the costs of the prevention programme implementation could be avoided [26]. According to Slover et al. [27] the cost of SSI associated with these procedures is so great that the cost of a screening programme would be recovered by only a small decrease in infection rate. Reducing the infections will decrease hospitalization time and increase the availability of beds for more days. With this, patients would enter and leave the hospital at a faster rate, reducing the average cost per patient treated [26].

It is also crucial to develop methods for the early detection of arthroplasty's infection, based on symptoms such as fever, pain, and tumefaction. If early detection was achieved, the infection could be treated by debridement and implant retention. In this way, costs would be significantly reduced, shortening the recovery period, and avoiding the costly two-stage revisions [18]. Hereupon, every effort is justified in order to prevent infection such as strict epidemiological surveillance and prevention programmes to avoid factors that may contribute to the onset of infection and, above all, best clinical practices of all staff involved in surgery [28].

In view of the increased costs related with these infections, the aim of this study is to perform a systematic review about the infection costs of hip and knee arthroplasties in several countries around the world, in order to better understand their economic impact.

\section{Methodology}

The systematic literature review was done according to the PRISMA guidelines [29].

\section{Database search}

Research was carried out in April 2016 using B-ON, PubMed, and Science Direct databases in order to find articles related with hip or knee arthroplasty infection costs, published between January 2005 and April 2016. To carry out this research, a combination of terms (Table 1) and an inclusion criterion (publication period) were applied. In each database, searches were performed separately for hip and knee arthroplasties. After carrying out both searches within each one of these databases, the articles that are repeated were excluded.

As a result of this research method, 37 articles were identified from PubMed, 38 from B-ON, and 29 from Science Direct. 
Table 1. MeSH and terms related.

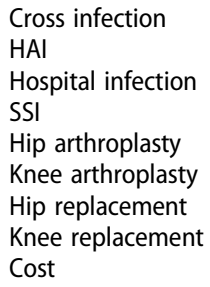

Table 2. Inclusion and exclusion criteria.

\begin{tabular}{|c|c|}
\hline $\begin{array}{l}\text { Inclusion criteria } \\
\text { - } \quad \text { Publication year: January } 2005 \text { to } \\
\text { April 2016; } \\
\text { - Language: English, Portuguese, } \\
\text { and Spanish; } \\
\text { - Contain abstract; } \\
\text { - Only apply to hospitals with } \\
\text { Orthopaedic services/department; } \\
\text { - } \quad \text { Be published and available in a } \\
\text { journal in public domain; } \\
\text { - } \text { Discuss about costs for hip or } \\
\text { knee arthroplasty; } \\
\text { - Discuss about costs for infections } \\
\text { treatment applied to hip or knee } \\
\text { arthroplasty; } \\
\text { - Discuss about cost-effectiveness } \\
\text { of strategies claiming to reduce } \\
\text { the risk of hip or knee arthroplasty } \\
\text { infections. }\end{array}$ & $\begin{array}{l}\text { Exclusion criteria } \\
\text { - Articles not related with hip or } \\
\text { knee arthroplasty infections; } \\
\text { - Articles with description of } \\
\text { methods, models, and theories } \\
\text { without empirical data; } \\
\text { - Other healthcare entities that } \\
\text { are not hospitals. }\end{array}$ \\
\hline
\end{tabular}

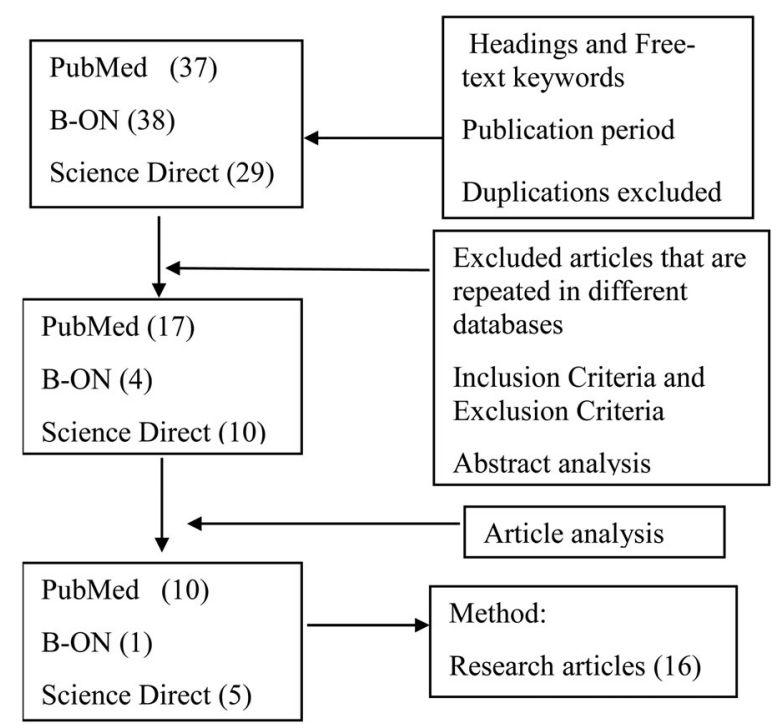

Figure 1. Search strategy.

To the articles obtained from this initial research method, more inclusion and exclusion criteria were applied (Table 2). In order to keep only one copy of each article, we exclude the repetition of the same article in different databases. A final number of 31 articles were obtained: PubMed [17], B-ON [4], and Science Direct [10].

After verification and further evaluation of the 31 articles, only 16 fulfilled every criteria of inclusion: PubMed [10], B-ON [1], and Science Direct [5], as shown in Figure 1.

\section{Data collection and analysis}

After the analysis of each article, the following data were extracted in an excel file: article name, publication year, country, setting (hospitals, teaching hospitals, tertiary care centre), study methodology, keywords, summary, and topics (key points).

\section{Results}

Through the literature review performed, we identified a number of key issues responsible for the increased hospitalization costs, as well as the costs of some treatments and prevention methods for hip or knee arthroplasty infections, which can reduce costs and patient suffering.

\section{Costs for hospitalization and infection treatment}

In Table 3 are presented the results of different studies in several countries, divided into two major dimensions: hospitalization and treatment. With regard to hospitalization, the charges will be presented in LOS and/or monetary costs. With regard to treatment, the charges will be presented in number of surgeries and LOS, or monetary costs.

\section{Infection prevention and control}

In Table 4 are presented the results of a study conducted in Australia. The researchers evaluated the cost-effectiveness of implemented strategies claiming to reduce the risk of deep SSI in hip arthroplasties.

\section{Discussion}

Through the literature review performed, we identified the main costs caused by HAI in hip and knee arthroplasties and the costs of some treatments and prevention methods for these situations. In agreement with the current state of the art, this review identified LOS as the indicator most commonly used to estimate the direct costs of SSIs, and according to some authors, this happens because, in addition to the direct relationship between the LOS and the risk of HAI, the extension of hospitalization days is an easily understood measure either by physicians or by hospital managers, which translates in the consumption of health resources to treat a complication $[21,35,43]$. According to Plowman [6], patients who developed HAI remained in hospital 2.5 times longer and incurred hospital costs almost three times higher, when compared with an uninfected patient who underwent the same surgical procedure. According to the articles reviewed, and with regard to LOS and HAI's treatment costs, the results were very similar to those found in the literature related with HAI issues. 
Table 3. Costs for hospitalization and infection treatment.

\begin{tabular}{|c|c|c|c|c|}
\hline \multirow[b]{2}{*}{ Dim } & \multirow[b]{2}{*}{ Authors } & \multirow[b]{2}{*}{ Study description } & \multicolumn{2}{|r|}{ Costs } \\
\hline & & & Arthroplasty without HAI & Arthroplasty with HAI \\
\hline \multirow[t]{14}{*}{ Hospitalization } & $\begin{array}{l}\text { Jodra et al. } \\
\text { [21] }\end{array}$ & $\begin{array}{l}\text { Study conducted in Madrid, between January } \\
2000 \text { and June } 2004 \text {. Additional cost for } \\
\text { infection treatment based on excess LOS } \\
\text { attributable to hip arthroplasty infections was } \\
\text { estimated. }\end{array}$ & $\begin{array}{l}\text { Hip: } \\
\text { Average LOS: } 17 \text { days } \\
\text { The mean cost per day for a } \\
\text { patient admitted to the } \\
\text { orthopaedic unit: } 437.44 € \text {. }\end{array}$ & $\begin{array}{l}\text { Hip: } \\
\text { Average LOS: } 53 \text { days } \\
\text { Additional cost per patient who } \\
\text { develops SSI : } 14,216.80 €\end{array}$ \\
\hline & Irribaren et al. & Comparative case-control study carried out in & Hip: & Hip: \\
\hline & [28] & $\begin{array}{l}\text { Chile, between January } 2000 \text { and December } \\
2004 \text { about excessive direct costs attributed to } \\
\text { hip arthroplasty infections. }\end{array}$ & $\begin{array}{l}\text { Average LOS: } 13 \text { days } \\
\text { Average cost: } \$ 2354\end{array}$ & $\begin{array}{l}\text { Average LOS: } 54 \text { days } \\
\text { Average cost: } \$ 6174,8 \text { (additional } \\
\text { cost : } \$ 3820,1)\end{array}$ \\
\hline & $\begin{array}{l}\text { Coello et al. } \\
\text { [30] }\end{array}$ & $\begin{array}{l}\text { Study conducted in England, based on } \\
\text { surveillance data of SSI from } 140 \text { English } \\
\text { hospitals, included in NINSS (National } \\
\text { Nosocomial Infection Surveillance Service), } \\
\text { between October } 1997 \text { and June } 2001 .\end{array}$ & $\begin{array}{l}\text { Hip: } \\
\text { Average LOS: } 11.1 \text { days } \\
\text { Knee: } \\
\text { Average LOS: } 10.3 \text { days }\end{array}$ & $\begin{array}{l}\text { Hip: } \\
\text { Average LOS: } 22.6 \text { days } \\
\text { Additional cost: } \$ 3342 \\
\text { Knee: } \\
\text { Average LOS: } 21.2 \text { days } \\
\text { Additional cost : } \$ 3168\end{array}$ \\
\hline & Alp et al. [31] & $\begin{array}{l}\text { Study conducted in Turkey, between April } 2011 \\
\text { and April 2013, to evaluate the incidence and } \\
\text { economic burden of prosthetic joint infections. }\end{array}$ & $\begin{array}{l}\text { Hip and Knee: } \\
\text { Average LOS: } 7 \text { days } \\
\text { Average cost: } \$ 5937\end{array}$ & $\begin{array}{l}\text { Hip and Knee: } \\
\text { Average LOS: } 49 \text { days } \\
\text { Average cost: } \$ 16999\end{array}$ \\
\hline & $\begin{array}{l}\text { Poultsides } \\
\text { et al. [32] }\end{array}$ & $\begin{array}{l}\text { Study conducted in USA to analyse the } \\
\text { hospitalization data from the National Inpatient } \\
\text { Sample (NIS) for hip and knee arthroplasties } \\
\text { between } 1998 \text { and } 2007 \text {. }\end{array}$ & $\begin{array}{l}\text { Hip: } \\
\text { Average LOS: } 4.2 \text { days } \\
\text { Average cost: } \$ 14,286 \\
\text { Knee: } \\
\text { Average LOS: } 4 \text { days } \\
\text { Average cost: } \$ 1,334\end{array}$ & $\begin{array}{l}\text { Hip: } \\
\text { Average LOS: } 13.4 \text { days } \\
\text { Average cost: } \$ 31432 \\
\text { Knee: } \\
\text { Average LOS: } 9.7 \text { days } \\
\text { Average cost: } \$ 24458\end{array}$ \\
\hline & $\begin{array}{l}\text { Kurtz et al. } \\
\text { [33] }\end{array}$ & $\begin{array}{l}\text { Study conducted in USA, based on NIS to identify } \\
\text { the primary and revision arthroplasty } \\
\text { performed between January } 2001 \text { and } \\
\text { December } 2009 \text { and to predict the economic } \\
\text { impact of periprosthetic joint infection on the } \\
\text { US health system. }\end{array}$ & - & $\begin{array}{l}\text { Hip: } \\
\text { Average of cost and LOS: } \\
\text { 2001: } \$ 31300 ; 11.5 \text { days } \\
\text { 2009: } \$ 30300 ; 9.5 \text { days } \\
\text { Knee: } \\
\text { Average of cost and LOS: } \\
\text { 2001: } \$ 25300 ; 9.3 \text { days } \\
\text { 2009: } \$ 24200 ; 7.2 \text { days }\end{array}$ \\
\hline & $\begin{array}{l}\text { Kapadia et al. } \\
\text { [34] }\end{array}$ & $\begin{array}{l}\text { Study with a group control conducted in USA, } \\
\text { between January } 2007 \text { and December } 2011 . \\
\text { The impact of periprosthetic joint infections on } \\
\text { the LOS, readmissions and associated costs } \\
\text { measured. }\end{array}$ & $\begin{array}{l}\text { Knee: } \\
\text { Average LOS: } 3 \text { days } \\
\text { Days in hospital (mean): } 3.4 \\
\text { days } \\
\text { Readmissions (mean): } 0.14 \\
\text { Average cost: } \$ 28249.57\end{array}$ & $\begin{array}{l}\text { Knee: } \\
\text { Average LOS: } 5.3 \text { days } \\
\text { Days in hospital (mean): } 23.7 \text { days } \\
\text { Readmissions (mean): } 3.43 \\
\text { Average cost: } \$ 116382.65\end{array}$ \\
\hline & $\begin{array}{l}\text { Dal-Paz et al. } \\
\text { [35] }\end{array}$ & $\begin{array}{l}\text { Study conducted between } 2006 \text { and } 2007 \text { in } \\
\text { Brazil to estimate the direct costs of the } 34 \\
\text { patients' treatment who acquired knee } \\
\text { arthroplasty infections, by analyzing medical } \\
\text { records. }\end{array}$ & - & $\begin{array}{l}\text { Knee: } \\
\text { Average LOS: } 29,7 \text { days } \\
\text { Additional Average |Cost: } \$ 2,701.29\end{array}$ \\
\hline & $\begin{array}{l}\text { Garrido- } \\
\text { Gómez et al. } \\
\text { [18] }\end{array}$ & $\begin{array}{l}\text { Retrospective study conducted between January } \\
2005 \text { and January } 2010 \text { in Spain, with } 79 \\
\text { patients who were diagnosed and treated for } \\
\text { knee arthroplasty infection. }\end{array}$ & - & $\begin{array}{l}\text { Knee: } \\
\quad \text { Average Cost: } 40542 € .\end{array}$ \\
\hline & $\begin{array}{l}\text { Klouche et al. } \\
\text { [36] }\end{array}$ & $\begin{array}{l}\text { Retrospective study conducted in France } \\
\text { between January and December 2006, to } \\
\text { determine the cost of revision of infected hip } \\
\text { arthroplasty and to compare these costs to } \\
\text { those of primary and revision of non-infected } \\
\text { hip arthroplasty. }\end{array}$ & $\begin{array}{l}\text { Hip: } \\
\text { Average cost of primary } \\
\text { arthroplasty: } 9028 € \\
\text { Average cost of aseptic } \\
\text { revision : } 12409 €\end{array}$ & $\begin{array}{l}\text { Hip: } \\
\text { Average Cost of septic revision: } 32 \\
546 €\end{array}$ \\
\hline & Peel et al. [37] & $\begin{array}{l}\text { Study conducted at St. Vincent's Hospital } \\
\text { Melbourne, between January } 2011 \text { and June } \\
\text { 2012, to evaluate the direct hospital costs in the } \\
\text { first 30-day follow-up of patients undergoing } \\
\text { total hip and knee arthroplasties (data were } \\
\text { extrapolated for Australian population). }\end{array}$ & - & $\begin{array}{l}\text { Hip and Knee: } \\
\text { SSI raise the arthroplasty's cost } \\
\text { around } 76 \% \text { in the hip, and around } \\
54 \% \text { in the knee. } \\
\text { The estimated average cost in the } \\
\text { first } 30 \text { days following surgery to } \\
\text { Australian population: } \$ 97.2 \text { million } \\
\text { AU }\end{array}$ \\
\hline & $\begin{array}{l}\text { González- } \\
\text { Vélez et al. } \\
\text { [38] }\end{array}$ & $\begin{array}{l}\text { A matched case-control study conducted at } \\
\text { Ramon y Cajal University Hospital in Spain } \\
\text { between } 1 \text { January } 2005 \text { and } 31 \text { December } \\
\text { 2011. The researchers estimated the excess } \\
\text { direct costs of hip arthroplasty }\end{array}$ & $\begin{array}{l}\text { Hip: } \\
\text { Average LOS: } 21 \text { days } \\
\text { Average Cost : } 10828 €\end{array}$ & $\begin{array}{l}\text { Hip: } \\
\text { Average LOS: } 58 \text { days } \\
\text { Average Cost :25 } 288 €\end{array}$ \\
\hline & Gow et al. [39] & $\begin{array}{l}\text { Retrospective case-control study conducted at } \\
\text { Auckland City Hospital (New Zealand) to } \\
\text { determine the excess costs attributable to hip } \\
\text { and knee arthroplasty infections. }\end{array}$ & - & $\begin{array}{l}\text { Hip and Knee: } \\
\text { Excess Average LOS: } 42 \text { days } \\
\text { Excess Average Cost: } \$ 40,121\end{array}$ \\
\hline
\end{tabular}


Table 3. Continued.

\begin{tabular}{|c|c|c|c|c|}
\hline \multirow[b]{2}{*}{ Dim } & \multirow[b]{2}{*}{ Authors } & \multirow[b]{2}{*}{ Study description } & \multicolumn{2}{|r|}{ Costs } \\
\hline & & & Arthroplasty without HAI & Arthroplasty with HAI \\
\hline \multirow[t]{2}{*}{ Treatment } & $\begin{array}{l}\text { Merollini et al. } \\
\text { [40] }\end{array}$ & $\begin{array}{l}\text { Study conducted in Australia, with patients } \\
\text { undergoing primary hip arthroplasty and } \\
\text { treatment for infection between January } 2006 \\
\text { and December } 2009 \text {. Different treatments costs } \\
\text { were identified from } 114 \text { patients with deep } \\
\text { hip arthroplasty infection. }\end{array}$ & - & $\begin{array}{l}\text { Hip: } \\
\text { Debridement, antibiotics and implant } \\
\text { retention: } \\
\text { Average cost per patient: } \$ 19688 \\
\text { AU } \\
\text { 1-stage revision: } \\
\text { Average cost per patient: } \$ 26722 \\
\text { AU } \\
\text { 2-stage revision: } \\
\text { Average cost per patient: } \$ 44744 \\
\text { AU } \\
\text { excision of arthroplasty: } \\
\text { Average cost per patient: } \$ 23805 \\
\text { AU }\end{array}$ \\
\hline & $\begin{array}{l}\text { Moojen et al. } \\
\text { [41] }\end{array}$ & $\begin{array}{l}\text { Retrospective study of a prospective database } \\
\text { conducted in two large teaching hospitals in } \\
\text { Holland, between } 2001 \text { and 2008. Data from } 68 \\
\text { patients treated to a deep postoperative } \\
\text { infection of a total hip arthroplasty were } \\
\text { obtained. One of the hospitals used a single } \\
\text { surgical debridement to treat the infection, the } \\
\text { other used a system with multiple surgical } \\
\text { debridement. }\end{array}$ & - & $\begin{array}{l}\text { Hip: } \\
\text { Single surgical debridement: } \\
\text { Average number of surgeries: } 1 \\
\text { Average length of antibiotic } \\
\text { treatment: } 13 \text { weeks; } \\
\text { Average LOS: } 29 \text { days. } \\
\text { Multiple surgical debridement: } \\
\text { Average number of surgeries: } 3 \\
\text { Average length of antibiotic } \\
\text { treatment: } 23 \text { weeks; } \\
\text { Average LOS: } 59 \text { days }\end{array}$ \\
\hline
\end{tabular}

It can also be concluded that comparing the LOS and treatment costs between hip arthroplasty infection and knee arthroplasty infection, the first were, in general, higher. Also, and being more specific, patients who developed deep incisional and organ/space SSI, in case of hip or knee arthroplasties, remained in hospital two times longer than those with superficial SSI $[21,30]$.

In addition to the LOS average cost, some articles reviewed were even more specific, discriminating the antimicrobial costs, readmission's number, laboratory tests and even the influence of age, gender, and race in HAI's treatment costs. According to Iribarren et al. [28], in cases of arthroplasty infection, only the antimicrobial's additional costs was about $\$ 2421$ per patient treated. According to Dal-Paz et al. [35], the additional costs in antibiotic therapy and laboratory tests to treat infections of a knee replacement, were approximately $\$ 600$ per patient.

Besides the extension of the LOS, the readmission's number also undergo a considerable change. Kapadia et al. [34], in his study about knee arthroplasty infections, concluded that the readmission's rate increased about four times in infected patients.

Besides the costs previously referenced, another USA-based study went further and concluded that there are other factors related to the patient and with its geographical location, even within the same country, which will affect the HAI's treatment costs [33]: Patients from different geographic locations generate different costs, e.g. patients living in the South or the Midwest had a lower cost $(\$ 4000-\$ 5000)$ than those in the West or the Northeast. The patient's race also has an influence on costs, e.g. Asian and African-American patients generated, on average, an additional expense of $\$ 4700$ and $\$ 1700$, respectively, when compared with caucasian patients. Another important issues are age and gender, e.g. at a given age level, female patients incurred a higher HAI's treatment cost than male patients, with particular emphasis in the ranges between the ages 45 and 54 years and the ages 75 and 79 years.

\section{Treatment}

Regarding HAI's treatment method, as mentioned previously, the state of art reveals that if early detection was achieved, the infection could be treated by debridement and implant retention [18]. According to Merollini et al. [40] study, four HAIs treatment methods were applied. They concluded that the treatment with debridement, antibiotics, and implant retention, had an average cost around $\$ 19,688 \mathrm{AU}$ and a two-stage revision had an average cost of $\$ 44,744 \mathrm{AU}$, which is more than double than the first one. The importance of primary prevention should not be ignored, because the occurrence of SSI might be reduced by introducing more cost-effective infection prevention measures.

According to Moojen et al. [41], we should aim treatment strategies that are both efficient and costeffective. They concluded that the strategy of a single debridement appears to be at least as successful for retention of the primary implant and control of infection as a strategy with multiple surgical debridements, without compromising the clinical effectiveness. However, considering equal clinical results, the first one will reduce the costs of multiple surgeries (2 less surgeries), hospitalizations ( 2 times lower), and revision implants. The single debridement will also reduce the morbidity and psychological discomfort of the patient. 
Table 4. Cost of strategies to prevent infection.

\begin{tabular}{|c|c|c|c|c|c|}
\hline Authors & Study description & Strategies & Costs & QALY* & Savings per QALY* \\
\hline \multirow[t]{3}{*}{$\begin{array}{l}\text { Merollini } \\
\text { et al. [42] }\end{array}$} & $\begin{array}{l}\text { At this study, the researchers simulated long- } \\
\text { term health and cost outcomes of a } \\
\text { hypothetical cohort of } 30,000 \text { patients } \\
\text { undergoing total hip arthroplasty. }\end{array}$ & $\begin{array}{l}\text { AP vs. no } \\
\text { AP }\end{array}$ & $\begin{array}{l}\text { No AP would } \\
\text { increase costs by } \\
\text { about } \$ 1.5 \text { million } \\
\text { AU }\end{array}$ & $\begin{array}{l}\text { No AP would lose } \\
163 \text { QALYs. }\end{array}$ & - \\
\hline & $\begin{array}{l}\text { Baseline use of } A P \text { was compared with no AP, } \\
\text { antibiotic-impregnated cement }(A P+A B C), \\
\text { and laminar air operating rooms (AP + LOR). }\end{array}$ & $\begin{array}{l}\text { AP vs. (AP } \\
+A B C)\end{array}$ & $\begin{array}{l}(A P+A B C) \text { would } \\
\text { save about } \$ 126 \\
000 \mathrm{AU}\end{array}$ & $\begin{array}{l}(A P+A B C) \text { would } \\
\text { generate an } \\
\text { extra } 32 \text { QALYs }\end{array}$ & $\begin{array}{l}\text { The use of }(A P+A B C) \text { would } \\
\text { prevent } 46 \text { deep infections } \\
\text { and would save } \$ 3,909 A U \\
\text { per QALY gained }\end{array}$ \\
\hline & & $\begin{array}{l}\text { AP vs. (AP } \\
+ \text { LOR) }\end{array}$ & $\begin{array}{l}(\mathrm{AP}+\mathrm{LOR}) \text { would } \\
\text { increase costs by } \\
\text { about } \$ 4.6 \text { million } \\
\text { AU }\end{array}$ & $\begin{array}{l}(\mathrm{AP}+\mathrm{LOR}) \text { would } \\
\text { lose } 127 \text { QALYs. }\end{array}$ & - \\
\hline
\end{tabular}

${ }^{*} \mathrm{QALY}$ - quality-adjusted life years.

\section{Prevention}

Regarding infection prevention and control methods, several studies show resources or costs that may be saved through effective prevention programmes. However, authors do not provide information about the cost of infection prevention efforts or number and qualityof-life years gained through those investments [26].

If costs are reduced by the implemented changes, there is no need to show the health benefits in terms of years of life gained or quality-adjusted life years gained. However, in cases where the cost savings do not compensate the increase of total costs, the health outcomes need to be demonstrated [26].

According to Merollini, Crawford et al. [42], scarce resources should be used efficiently and for this, it is important to establish a cost-effective approach to preventing SSI in the total hip arthroplasty. The prevention of these infections can not only be centred in costs reduction but also in patient's suffering reduction. The additional use of antibiotic-impregnated (AP+ $A B C)$, compared with only antibiotic prophylaxis (AP), would prevent 46 deep SSI and save $\$ 3,909$ for each QALY gained, leading to cost savings. Using antibiotic cement in addition to antibiotic prophylaxis (AP $+\mathrm{ABC}$ ) would generate an extra 32 QALYs while saving over AUD $\$ 123,000$. Not using AP would increase costs by approximately $\$ 1.5$ million with a 163 QALYs lost. Using laminar air operating rooms (AP+ LOR) would increase costs by approximately $\$ 4.6$ million, and 127 QALYs are lost. If all hospitals adopted the antibiotic-impregnated cement strategy $(\mathrm{AP}+\mathrm{ABC})$, besides improving health outcomes among hospitalized patients and save lives, they could save many resources that could be used in other areas in need.

\section{Conclusion}

Quantifying the exact economic impact of HAI is an ongoing international challenge and the use of the direct hospitalization costs has been suggested as the best method to estimate the direct HAI's costs. These represent the real costs to the hospital for the items and services used by each patient and have a direct impact on hospital budget.

This study has some limitations, mainly related with the difficulties to obtain articles related with HAI cost analysis from databases, and limited access to cost information (e.g. no cost discrimination).

In the majority of the articles reviewed in this study, the cost analyses of HAI, more specifically about hip and knee arthroplasties infections, focus primarily on direct hospitalization costs. The LOS was the most commonly used indicator to estimate the direct costs of these SSIs in the reviewed articles. By using this indicator, evidence suggests that patients who developed HAI remained in hospital 2.5-3 times longer and incurred hospital costs almost three times higher, when compared with an uninfected patient who underwent the same surgical procedures. However, this indicator is restricted to the direct medical costs, and does not include information with regard to the real cost to patients and society in lost earnings (indirect costs).

The measurement of indirect cost is indeed a fundamental healthcare management challenge as there is high degree of difficult to account for exact cost and, generally, these are assumed to be much higher than direct costs. Thus, evidence gathered in this article allows us to argue that the cost analysis of HAI performed in international studies has been continuously underestimating real economic impacts of HAI in hip and knee arthroplasties. This key idea can no longer be ignored by healthcare managers and decision makers and further research must be done to explore better these issues. 


\section{References}

[1] Garner J, Jarvis W, Emori T, et al. CDC definitions for nosocomial infections. In RN. Olmsted, editor. APIC control and applied epidemiology: principles and practices. St. Louis: Mosby Year Book Inc; 1996.

[2] Horan TC, Andrus M, Dudeck MA. CDC/NHSN surveillance definition of health care-associated infection and criteria for specific types of infections in the acute care setting. Am J Infect Control. 2008;36 (5):309-332.

[3] Graves N. Economics and preventing hospitalacquired infection. Emerg Infect Dis. 2004;10(4):561566.

[4] McFee RB. Nosocomial or hospital-acquired infections: an overview. Dis Mon. 2009;55(7):422-438.

[5] Peña C, Pujol M, Pallarés R, et al. Estimación del coste atribuible a la infección nosocomial: prolongación de la estancia hospitalaria y cálculo de costes alternativos. Med Clín. 1996;106(12):441-444.

[6] Plowman R. The socioeconomic burden of hospital acquired infection. Euro Surveill. 2000;5(4):49-50.

[7] Haley RW. Measuring the costs of nosocomial infections: methods for estimating economic burden on the hospital. Am J Med. 1991;91(3):S32-S38.

[8] Grammatico-Guillon L, Rusch E, Astagneau P. Surveillance of prosthetic joint infections: international overview and new insights for hospital databases. J Hosp Infect. 2015;89(2):90-98.

[9] Baylina P, Moreira P. Challenging healthcare-associated infections: a review of healthcare quality management issues. J Manag Marketing Healthc. 2011;4(4):254-264.

[10] Edmond M, Wenzel R. National and international surveillance systems for nosocomial infections. Prevention and control of nosocomial infections. 4th ed. Philadelphia: Lippincott Williams \& Wilkins; 2003. p. 109-119.

[11] WHO. WHO guidelines on hand hygiene in health care: first global patient safety challenge. Clean care is safer care: World Health Organization; 2009.

[12] WHO. WHO guidelines for safe surgery: 2009: safe surgery saves lives. 2009.

[13] EuropeanCommission. Prevention of hospital infections by intervention \& training (PROHIBIT). Available from: http://www.who.int/patientsafety/ implementation/bsi/prohibit-outcomes/en/. 2010.

[14] Frank U, Group BS. The BURDEN project - assessing the burden of resistance and disease in Europe. Euro Surveill. 2007;12(1):E070111), 5.

[15] ECDC. Healthcare-associated infections surveillance network (HAI-Net). Available from: http://ecdc. europa.eu/en/healthtopics/Healthcare-associated_ infections/HAI-Net/Pages/HAI-Net-surveillancenetwork.aspx. 2011.

[16] Baylina P, Moreira P. Healthcare-associated infections - on developing effective control systems under a renewed healthcare management debate. Inter $\mathrm{J}$ Healthc Manag. 2012;5(2):74-84.

[17] Widmer AF. New developments in diagnosis and treatment of infection in orthopedic implants. Clin Infect Dis. 2001;33(Supplement 2):S94-S106.

[18] Garrido-Gómez J, Arrabal-Polo MA, Girón-Prieto MS, et al. Descriptive analysis of the economic costs of periprosthetic joint infection of the knee for the public health system of Andalusia. J Arthroplasty. 2013;28 (7):1057-1060.

[19] Taylor EN, Webster TJ. The use of superparamagnetic nanoparticles for prosthetic biofilm prevention. Inter J Nanomed. 2009;4:145-152.

[20] Bertucci FN, Tedrus GMAS, editors. Infecções em próteses ortopédicas: revisão da literatura. Anais do XV Encontro de Iniciação Científica da PUCCampinas 2010; Campinas.

[21] Jodra VM, de los Terreros Soler LS, Perez CD-A, et al. Excess length of stay attributable to surgical site infection following hip replacement: a nested case-control study. Infect Control. 2006;27(12):1299-1303.

[22] Trampuz A, Zimmerli W. Prosthetic joint infections: update in diagnosis and treatment. Swiss Med Wkly. 2005;135(17-18):243-251.

[23] López-Contreras J, Limón E, Matas L, et al. Epidemiology of surgical site infections after total hip and knee joint replacement during 2007-2009: a report from the VINCat Program. Enferm Infecc Microbiol Clín. 2012;30:26-32.

[24] Ercole FF, Chianca TCM. Infecção de sítio cirúrgico em pacientes submetidos à artroplastia de quadril. Rev Lat Am Enfermagem. 2002;10(2):157-165.

[25] Freitas F, Virgolino M, Ribeiro C. Infecção de prótese articular da anca e joelho. Revista Portuguesa de Ortopedia e Traumatologia. 2013: 165-172.

[26] Graves N. How costs change with infection prevention efforts. Curr Opin Infect Dis. 2014;27(4):390-393.

[27] Slover J, Haas JP, Quirno M, et al. Cost-effectiveness of a staphylococcus aureus screening and decolonization program for high-risk orthopedic patients. J Arthroplasty. 2011;26(3):360-365.

[28] Osvaldo Iribarren B, Alejandra Álvarez C, Cristian Rodríguez $\mathrm{C}$, et al. Costo y desenlace de la infección de artroplastía de cadera: Estudio de caso y control. Rev Chil Infect. 2007;24:125-130.

[29] Liberati A, Altman DG, Tetzlaff J, et al. The PRISMA statement for reporting systematic reviews and metaanalyses of studies that evaluate health care interventions: explanation and elaboration. Ann Intern Med. 2009;151(4):W-65-W-94.

[30] Coello R, Charlett A, Wilson J, et al. Adverse impact of surgical site infections in English hospitals. J Hosp Infect. 2005;60(2):93-103.

[31] Alp E, Cevahir F, Ersoy S, et al. Incidence and economic burden of prosthetic joint infections in a university hospital: a report from a middle-income country. J Infect Public Health. 2016;9(4):494-498.

[32] Poultsides LA, Ma Y, Della Valle AG, et al. In-Hospital surgical site infections after primary hip and knee arthroplasty - incidence and risk factors. J Arthroplasty. 2013;28(3):385-389.

[33] Kurtz SM, Lau E, Watson H, et al. Economic burden of periprosthetic joint infection in the United States. J Arthroplasty. 2012;27(8, Supplement):61-65. e1.

[34] Kapadia BH, McElroy MJ, Issa K, et al. The economic impact of periprosthetic infections following total knee arthroplasty at a specialized tertiary-care center. J Arthroplasty. 2014;29(5):929-932. 
[35] Dal-Paz K, Oliveira PR, de Paula AP, et al. Economic impact of treatment for surgical site infections in cases of total knee arthroplasty in a tertiary public hospital in Brazil. Braz J Infect Dis. 2010;14(4):356-359.

[36] Klouche S, Sariali E, Mamoudy P. Total hip arthroplasty revision due to infection: a cost analysis approach. Orthop TraumatolSur Res. 2010;96(2):124-132.

[37] Peel T, Cheng A, Liew D, et al. Direct hospital cost determinants following hip and knee arthroplasty. Arthrit Care Res. 2015;67(6):782-790.

[38] González-Vélez AE, Romero-Martín M, VillanuevaOrbaiz R, et al. The cost of infection in hip arthroplasty: a matched case-control study. Rev Esp Cir Ortop Traumatol. 2016;60(4):227-233.

[39] Gow N, McGuinness C, Morris A, et al. Excess cost associated with primary hip and knee joint arthroplasty surgical site infections: a driver to support investment in quality improvement strategies to reduce infection rates. NZ Med J. 2016;129(1432):51-58.

[40] Merollini KMD, Crawford RW, Graves N. Surgical treatment approaches and reimbursement costs of surgical site infections post hip arthroplasty in Australia: a retrospective analysis. BMC Health Serv Res. 2013;13:1157.

[41] Moojen DJF, Zwiers JH, Scholtes VAB, et al. Similar success rates for single and multiple debridement surgery for acute hip arthroplasty infection. Acta orthopaedica. 2014;85(4):383-388.

[42] Merollini KMD, Crawford RW, Whitehouse SL, et al. Surgical site infection prevention following total hip arthroplasty in Australia: a cost-effectiveness analysis. Am J Infect Control. 2013;41(9):803-809.

[43] Martins MITM, Franco MJB, Duarte JC. Um estudo caso sobre os custos das infecções no Centro Hospitalar Cova da Beira. Rev Enf Ref. 2007;2(4):79-90. 